\title{
Nitric Oxide (NO) Modulates the Neurogenic Control of Blood Pressure in Rats with Chronic Renal Failure (CRF)
}

\author{
Shaohua Ye, Said Nosrati, and Vito M. Campese \\ Division of Nephrology, Department of Medicine, University of Southern California, Los Angeles, California 90033
}

\begin{abstract}
Increased sympathetic nervous system (SNS) activity plays a role in the genesis of hypertension in rats with chronic renal failure (CRF). Because nitric oxide (NO) modulates the activity of the SNS, a deficit of NO synthesis could be responsible for the increased SNS activity in these animals.

In the present study, we evaluated the effects of L-arginine and L-NAME on blood pressure and SNS activity in Sprague Dawley 5/6 nephrectomized or sham-operated rats. SNS activity was determined by measuring norepinephrine turnover rate in several brain nuclei involved in the regulation of blood pressure. In the same brain nuclei, we measured NO content and nitric oxide synthase (NOS) gene expression by semiquantitative measurements of NOS mRNA reverse transcription polymerase chain reaction.

In CRF rats, norepinephrine turnover rate was increased in the posterior hypothalamic nuclei, locus coeruleus, paraventricular nuclei, and the rostral ventral medulla, whereas NOS mRNA gene expression and $\mathrm{NO}_{2} / \mathrm{NO}_{3}$ content were increased in all brain nuclei tested. L-NAME increased blood pressure and NE turnover rate in several brain nuclei of both control and 5/6 nephrectomized rats.

In CRF rats, a significant relationship was present between the percent increment in NOS mRNA gene expression related to the renal failure, and the percent increase in norepinephrine turnover rate caused by L-NAME. This suggests that endogenous NO may partially inhibit the activity of the SNS in brain nuclei involved in the neurogenic regulation of blood pressure, and this inhibition is enhanced in CRF rats.

In summary, the increase in SNS activity in the posterior hypothalamic nuclei and in the locus coeruleus of CRF rats is partially mitigated by increased local expression of NOS m-RNA. (J. Clin. Invest. 1997. 99:540-548.) Key words: hypertension • chronic renal failure $\bullet$ nitric oxide $\bullet$ neurogenic factors
\end{abstract}

\section{Introduction}

Hypertension remains a significant clinical issue in the patient with chronic renal failure. Clearly, hypertension is an impor-

Address correspondence to Vito M. Campese, M.D., Division of Nephrology, LAC/USC Medical Center, 2025 Zonal Avenue, Los Angeles, CA 90033. Phone: 213-226-7303; FAX: 213-226-5390.

Received for publication 19 March 1996 and accepted in revised form 11 November 1996.

J. Clin. Invest.

(C) The American Society for Clinical Investigation, Inc. 0021-9738/97/02/0540/09 \$2.00

Volume 99, Number 3, February 1997, 540-548 tant etiology in the pathogenesis of renal failure. As the sole etiologic factor hypertension results in end-stage renal disease in $\sim 25 \%$ of patients on chronic renal replacement therapies in the United States. In conjunction with other diseases such as diabetes and chronic glomerulonephritides, hypertension when uncontrolled hastens the progression to end-stage renal disease.

Various factors may play a role in the pathogenesis of hypertension in chronic renal failure. Those include sodium retention and volume expansion, increased activity of vasoconstrictors, such as the renin-angiotensin system $(1,2)$, the sympathetic nervous system (SNS) ${ }^{1}(3-7)$, and endothelin (8). We have previously shown that the turnover rate of NE was significantly increased in the posterior hypothalamic nuclei and in the locus coeruleus, and chemical destruction of the posterior hypothalamic nuclei by microinjection of a neurotoxin, 6-OH-dopamine, reduced blood pressure in these animals (9).

Hypertension in rats with chronic renal failure could also be caused by a reduced production of endothelium-derived relaxing factor (EDRF; 10), known to be nitric oxide (NO) (1113). Nitric oxide synthase (NOS) is the enzyme involved in the production of NO-utilizing L-arginine as substrate $(13,14)$. NOS is competitively inhibited by $\mathrm{N}^{\mathrm{G}}$-monomethyl-L-arginine (LNMMA) or by $\mathrm{N}^{\mathrm{W}} \mathrm{L}$-nitro-L-arginine-methyl ester (L-NAME) and other L-arginine molecules that have substitutions on the guanidino nitrogen atoms (15). These inhibitors have been used as chemical probes of NO synthesis in vivo and in vitro. Chronic inhibition of NO synthesis by L-NAME causes a sustained elevation of blood pressure $(16,17)$, marked renal vasoconstriction and hypoperfusion, a 30\% fall in glomerular filtration rate, a $39 \%$ increase in filtration fraction, and a rise in plasma renin levels in normal rats (18). Sakuma et al. (19) showed that administration of $\mathrm{N}^{\mathrm{G}}$-methyl-L-arginine to male Wistar rats increases renal sympathetic nerve activity (RSNA) and blood pressure. This increase could be reduced by spinal $\mathrm{C}-1-\mathrm{C}-2$ transection, implying that NO plays a role in the regulation of sympathetic tone.

For this purpose, we evaluated the effects of L-arginine, L-NAME, or vehicle on blood pressure and on NE turnover rate in different brain nuclei involved in the neurogenic control of blood pressure. We also measured NO synthase gene expression and NO concentration in these brain nuclei.

\section{Methods}

Male Sprague-Dawley rats weighing 200-300 g were used for these studies. The animals were fed normal rat chow (ICN Nutritional Bio-

1. Abbreviations used in this paper: $\mathrm{CRF}$, chronic renal failure; $\mathrm{EtBr}$, ethidium bromide; L-NAME, $\mathrm{N}^{\mathrm{W}} \mathrm{L}$-nitro-L-arginine-methyl ester; NO, nitric oxide; NOS, nitric oxide synthase; SNS, sympathetic nervous system. 
chemical, Cleveland, $\mathrm{OH})$ throughout the study. Two groups of rats were used for these studies. One group underwent 5/6 nephrectomy (chronic renal failure [CRF] group) and the other received sham nephrectomy (control group). Sodium pentobarbital (35 mg/kg, i.p.) was used to anesthetize the rats. For the CRF model, rats first underwent two-thirds nephrectomy of the right kidney, and $1 \mathrm{wk}$ later they underwent total nephrectomy of the left kidney. CRF and sham operated rats were further divided into three subgroups. The first subgroup received distilled water ad libitum as drinking water. The second subgroup was given L-arginine $1.25 \mathrm{~g} /$ liter in the drinking water. The third subgroup was given L-NAME $(50 \mathrm{mg} / \mathrm{liter}$ of drinking water). Blood pressure measurements were performed weekly at 10:00 a.m. by the tail-cuff method, using an electrosphygmomanometer and physiograph recorder (model MK-III; Narco Bio-Systems, Houston, TX). Each blood pressure measurement was the average of six to eight readings. Blood samples were drawn from the tail of the animals before and 1,3, and $5 \mathrm{wk}$ after the 5/6 nephrectomy for measurement of serum creatinine. These serum creatinine were measured by autoanalyzer.

Norepinephrine turnover rate. Towards completion of the study, $300 \mathrm{mg} / \mathrm{kg}$ of $\alpha$-methyl-DL- -tyrosine methyl ester (DL-2methyl-3-[4hydroxyphenyl]-alanine methyl ester) hydrochloride (Sigma Chemical Corp., St. Louis, MO) diluted in $0.5 \mathrm{ml}$ of $0.9 \%$ saline was injected in the peritoneal cavity of all rats. Following the injection of $\alpha$-methyl$p$-tyrosine, rats were killed by decapitation immediately (0 time) or after 3 and $6 \mathrm{~h}$ and their brain and thoracic aorta were removed. The brains and thoracic aorta were then immediately frozen under powdered dry ice and stored at $-70^{\circ} \mathrm{C}$ for no longer than $3 \mathrm{wk}$. Later, we cut the brains into consecutive $200-\mu \mathrm{m}$ sections in a cryostat at $-20^{\circ} \mathrm{C}$ and obtained bilateral micropunches $0.5 \mathrm{~mm}$ in diameter from several brain nuclei using the following coordinates. For the anterior hypothalamic nuclei, the coordinates were A-P from bregma -1.1 to -1.9 $\mathrm{mm}$; lat. $\pm 0.9 ; \mathrm{v}=8.6 \mathrm{~mm}$ from skull surface, according to the Paxinos and Watson rat atlas $(20,21)$. The coordinates for the posterior hypothalamic nuclei were A-P from -3.5 to $-4.1 \mathrm{~mm}$; lat. $\pm 0.4 \mathrm{~mm}$; $\mathrm{v}=8 \mathrm{~mm}$. For the paraventricular nuclei coordinates were A-P from -1.4 to $-2.0 \mathrm{~mm}$; lat. $\pm 0.3 \mathrm{~mm} ; \mathrm{v}=7.9 \mathrm{~mm}$. For the locus coeruleus, A-P from -9.8 to $-10.2 \mathrm{~mm}$; lat. $\pm 1.4 \mathrm{~mm} ; \mathrm{v}=7.2 \mathrm{~mm}$. For the nucleus tractus solitarius, A-P from -11.6 to $-12.6 \mathrm{~mm}$; lat. $\pm 1.4 \mathrm{~mm}$; $\mathrm{v}=8.3 \mathrm{~mm}$. For the rostral ventrolateral medulla $\left(\mathrm{C}_{1}\right)$ the coordinates were A-P from -11.8 to $-12.8 \mathrm{~mm}$; lat. $\pm 2.3 \mathrm{~mm} ; \mathrm{v}=10 \mathrm{~mm}$. For the ventral ventrolateral medulla $\left(\mathrm{A}_{1}\right)$ we performed micropunches at two different levels with coordinates A-P -13.6 to -14.3 $\mathrm{mm}$; lat. $\pm 2.0 \mathrm{~mm} ; \mathrm{v}=9.9 \mathrm{~mm}$, and A-P from -14.31 to $-14.60 \mathrm{~mm}$; lat. \pm 2.4 ; and $\mathrm{v}=10.0 \mathrm{~mm}$, respectively. All brain samples and aorta were first sonicated in $0.03 \mathrm{~N}$ perchloric acid, then centrifuged $(10,000 \mathrm{~g}$ for $30 \mathrm{~s}$ ). The supernatants were assayed for NE and epinephrine by the radioenzymatic method of Peuler and Johnson (22). This assay is based on the use of the enzyme catechol- $O$-methyltransferase, which transfers a radioactive methyl group from $S$-[methyl- $\left.{ }^{3} \mathrm{H}\right]$ adenosylL-methionine to an endogenous catecholamine to form a radioactive $O$-methyl catecholamine derivative. The sensitivity of this method for $\mathrm{NE}$ and epinephrine is $1-2 \mathrm{pg}$.

$\mathrm{NE}$ turnover rate was calculated by assaying the endogenous $\mathrm{NE}$ concentration at time 0,3 , and $6 \mathrm{~h}$ after the intraperitoneal injection of $300 \mathrm{mg} / \mathrm{kg}$ of $\alpha$-methyl-DL- $p$-tyrosine methyl ester $(23,24)$. After $\alpha$-methyl- $p$-tyrosine, the endogenous tissue levels of NE decline at a rate proportional to the initial NE concentrations (25). The turnover rate of NE was calculated according to the method of Brodie et al. (26). The log of NE was plotted versus time and the least-square straight line provided the fractional turnover rate, $k$. The NE turnover $\left(\mathrm{pg} \cdot \mathrm{mg}^{-1} \cdot \mathrm{h}^{-1}\right)$ was calculated as the product of $k$ times the endogenous concentration of NE. The half-life was calculated from the equation $t_{1 / 2}=0.434$ divided by the slope. The $95 \%$ confidence intervals were determined for the turnover rates according to the method of Taubin et al. (27). A confidence interval of one standard error about the slope and endogenous concentration was established. The lower limit of the slope and the lower limits of the endogenous con- centrations were multiplied to obtain the lower $95 \%$ confidence limits for the mean turnover rates. Similarly, $95 \%$ confidence limits were determined for the upper intervals. Each data point includes at least five rats.

Material for RT-PCR. Random hexamers, DTT, Super Scrip reverse transcriptase with reaction buffer $(5 \times ; 20 \mathrm{mM}$ Tris- $\mathrm{HCl}, 10$ $\mathrm{mM} \mathrm{NaCl}, 0.1 \mathrm{mM}$ EDTA, $1 \mathrm{mM}$ DTT, $0.01 \% \mathrm{NP} 40$, and $50 \%$ glycerol), Taq DNA polymerase with reaction buffer $(10 \times ; 50 \mathrm{~mm}$ Tris$\mathrm{HCl}, 10 \mathrm{mM} \mathrm{NaCl}, 0.1 \mathrm{mM}$ EDTA, $5 \mathrm{mM}$ DTT, and 50\% glycerol, and $1.0 \%$ Triton X-100), deoxynucleotide mixture (dNTP) and $\mathrm{MgCl}_{2}$ were purchased from GIBCO BRL (Gaithersburg, MD).

RNA extraction. Total RNA was extracted by TRIzol Reagent. Briefly, brain nuclei samples obtained by the micropunch technique as previously described, were homogenized in $0.8 \mathrm{ml}$ TRIzol Reagent in a glass homogenizer and then incubated for $5 \mathrm{~min}$ at $30^{\circ} \mathrm{C}$. Chloroform $0.16 \mathrm{ml}$ was then added to homogenates, vortexed for $15 \mathrm{~s}$, then incubated at $30^{\circ} \mathrm{C}$ for additional $5 \mathrm{~min}$. The samples were then centrifuged at $10,000 \mathrm{~g}$ for $15 \mathrm{~min}$ at $4^{\circ} \mathrm{C}$. The aqueous phases were separated then mixed with $0.5 \mathrm{ml}$ isopropyl alcohol $(100 \%)$. The mixtures were incubated first at $30^{\circ} \mathrm{C}$ for $10 \mathrm{~min}$ and subsequently at $-20^{\circ} \mathrm{C}$ for $12 \mathrm{~h}$. Later, samples were centrifuged at $12,000 \mathrm{~g}$ for $20 \mathrm{~min}$ at $4^{\circ} \mathrm{C}$. The precipitate was washed twice with $1 \mathrm{ml}$ of $75 \%$ ethanol, air dried, and dissolved in $7 \mu$ l of diethyl pyrocarbonate (DEPC) treated water. The quantity and purity of total RNA for each sample was measured by OD at 260 and $280 \mathrm{~nm}$ (model Du-64 Spectrophotometer; Beckman Instruments, Inc., Fullerton, CA). Total RNA measurement of all samples ranged between 0.2 and $0.8 \mu \mathrm{g}$, OD $260 \mathrm{~nm} / \mathrm{OD} 280 \mathrm{~nm}$ between 1.65 and $1.9 \mu \mathrm{g}$. All samples were stored at $-70^{\circ} \mathrm{C}$ for the next part of these experiments.

Reverse transcription. Total RNA $(0.2-0.8 \mu \mathrm{g})$ was mixed with 3 $\mu \mathrm{l}$ of random hexamers primers $(0.5 \mathrm{ng} / \mu \mathrm{l})$, incubated at $70^{\circ} \mathrm{C}$ for 10 min then transferred on ice for 5 min. $9 \mu \mathrm{l}$ of RT reaction mixture (containing $4 \mu \mathrm{l}$ of $5 \times$ reaction buffer, $2 \mu \mathrm{l}$ of $25 \mathrm{mM} \mathrm{MgCl}_{2}, 1 \mu \mathrm{l}$ of $10 \mathrm{mM}$ deoxynucleotide mixture, and $2 \mu \mathrm{l}$ of 0.1 DTT) were added to each sample tube. The mixture was incubated at $25^{\circ} \mathrm{C}$ for $5 \mathrm{~min}$. Thereafter, $1 \mu \mathrm{l}(200 \mathrm{U})$ of Superscipt II reverse transcriptase was added and samples were incubated at $25^{\circ} \mathrm{C}$ for $10 \mathrm{~min}$ and at $42^{\circ} \mathrm{C}$ for $50 \mathrm{~min}$. Subsequently, the reaction mixture was heated to $70^{\circ} \mathrm{C}$ for 15 min to inactivate the reverse transcriptase, then chilled on ice for 5 min. $4 \mu \mathrm{l}$ of cDNA template were used for each PCR.

Polymerase chain reaction. Oligonucleotide primers for PCR were selected from the sequence of Rodentia rattus mRNA for brain nitric oxide synthase (Accession X59949; Genbank, National Center for Biotechnology Information, Bethesda, MD). Primer 1 was defined by bases $(2,500-2,620)$ sequence 5'-AAGAGGGTCAAGGCGACCATTC-3'; primer 2, bases 2,995-2,972, sequence 5'-cGAACACTGAGGAACCTCACATTGG-3'. The PCR product generated using these primers is 397-bp segment $(2,500-2,995)$. The primers for betaactin were as follows: primer 1 bases (268-289) 5'-TTCTACAATGAGCTGCGTGTGG-3' and primer 2 bases (806-783) 5'-ATACCCAGGAAGGAAGGCTGGAAG, the segment of PCR product was 539 bp (268-806). PCR for both NOS and beta-actin was performed under the same experimental conditions. The PCR reaction mixture contained $10 \mu \mathrm{l}$ of $10 \times$ PCR buffer, $5 \mathrm{U}$ Taq DNA polymerase, $4 \mu \mathrm{l}$ of cDNA, $\mathrm{MgCl}_{2} 2 \mathrm{mM}$, deoxynucleotide mixture 0.2 $\mathrm{mM}$, and $0.1 \mu \mathrm{M}$ each Primer set. The final volume of each PCR was $100 \mu$ l. Each reaction mixture tube was overlaid with $50 \mu \mathrm{l}$ mineral oil. The PCR was performed with DNA Thermal Cycler 480 (Perkin Elmer, Branchburg, NJ). The cycling programs were as follows: denaturation for $1 \mathrm{~min}$ at $94^{\circ} \mathrm{C}$, annealing for $1.5 \mathrm{~min}$ at $58^{\circ} \mathrm{C}$, and extension for $1.5 \mathrm{~min}$ at $72^{\circ} \mathrm{C}$. After completion of PCR ( 25 cycles for betaactin and 28 cycles for NOS), the thermal cycler was stopped in the course of an extension and $80 \mu \mathrm{l}$ of the reaction volume removed through the mineral oil from each vial to be used for quantification of RT-PCR. To make sure that the PCR reaction is appropriate, the remaining $20 \mu \mathrm{l}$ of the PCR mixture were subjected to an additional 15 cycles of amplification. Later, PCR products were separated on $1.5 \%$ agarose gel electrophoresis stained with EtBr. Only PCR products 
with a distinct target band corresponding to the appropriate product on the electrophoresis gel were used for further analysis.

Semi-quantification of RT-PCR. The RT-PCR products were quantified by a method based on that of Higuchi et al. (28). The PCR products from the RT-PCR reactions $(80 \mu \mathrm{l})$ were diluted 40 -fold with water. Then, EtBr was added to each sample to final concentration of $250 \mathrm{ng} / \mathrm{ml}$. Fluorescence was measured in a fluorescence spectrofluorometer (model F-2000; Hitachi Ltd., Tokyo, Japan). Excitation was at $280 \mathrm{~nm}$ and emitted light was selected at $590 \mathrm{~nm}$. The amount of both NOS mRNA and $\beta$-actin mRNA products were measured, and the ratio of these measurements calculated (NOS/ $\beta$-actin $\times 100 \%)$. This ratio was taken to express the NOS gene expression. To insure the amplification of the right message, the PCR products were determined by DNA sequences analysis.

Nitrate/nitrite assay. To determine $\mathrm{NO}$ concentrations in brain nuclei we measured the stable metabolites $\mathrm{NO}_{2}$ and $\mathrm{NO}_{3}$ using the Cayman's Kit (Alexis Corp., San Diego, CA). In brief, this assay is a two-step process. The first step is the conversion of nitrate to nitrite utilizing nitrate reductase. The second step is the addition of the Griess Reagents which convert nitrite into a deep purple azo compound, that can be measured by photometric method (Shimadzu Corp., Tokyo, Japan). Known concentrations of $\mathrm{NaNO}_{2}$ and $\mathrm{NaNO}_{3}$ are used as standards in each assay.

Effect of angiotensin II on BP and NE secretion. In five rats, we cannulated one femoral artery and one femoral vein under anesthesia. Subsequently, we infused angiotensin II $(8-16 \mathrm{ng} / \mathrm{min}$ i.v.) to achieve a systolic blood pressure of $\sim 180 \mathrm{mmHg}$. After stabilization of blood pressure to $\sim 180 \mathrm{mmHg}$ for $20 \mathrm{~min}$, rats were killed by decapitation and brains removed for future measurement of NOS mRNA expression in various brain nuclei.

Statistical analyses. The data were analyzed by one-way analysis of variance and the Scheffe's $F$ test for comparisons among groups and by simple regression analysis using the computer program Statview and Graphics 4.01. Values are given as mean \pm SEM.

\section{Results}

Blood pressure and serum creatinine. The data on body weight, blood pressure, and serum creatinine are summarized in Table I. In 5/6 nephrectomized rats (CRF) systolic blood pressure increased progressively with time and reached levels of $181 \pm 1.3$ $\mathrm{mmHg} 5 \mathrm{wk}$ postnephrectomy. During the same period of time, CRF rats treated with L-arginine $(1.25 \mathrm{~g} /$ liter of drinking water) reached systolic blood pressure levels of only $154 \pm 0.7$ $\mathrm{mmHg}$, which were significantly lower $(P<0.01)$ than those of untreated CRF rats, but still higher than the blood pressure levels in control animals treated with $\mathrm{L}$-arginine $(126 \pm 0.9$ $\mathrm{mmHg})$ or with vehicle alone $(127 \pm 1.0 \mathrm{mmHg})$. In CRF rats, after only $1 \mathrm{wk}$ of treatment with L-NAME $(50 \mathrm{mg} / \mathrm{liter}$ of drinking water) systolic blood pressure reached levels significantly higher than untreated CRF rats $(184 \pm 4.4$ vs. $157 \pm 1.4$ $\mathrm{mmHg} ; P<0.01)$. Most of the CRF rats treated with L-NAME died of brain hemorrhage between the third and fifth week after 5/6 nephrectomy. In control rats, treatment with L-NAME for $5 \mathrm{wk}$ resulted in a significant and progressive rise in systolic blood pressure, to levels of $164 \pm 2.0 \mathrm{mmHg}$. When we used the same amount of L-NAME in the drinking water $(50 \mathrm{mg} / \mathrm{liter})$, the increase in blood pressure was of $49 \pm 2.3 \mathrm{mmHg}$ in CRF rats and of $37 \pm 1.3 \mathrm{mmHg}$ in control rats. This, however, did not necessarily indicate a greater role for $\mathrm{NO}$ in the regulation of blood pressure in CRF compared with control rats because CRF rats treated with L-NAME drank more water than control rats. As a result, CRF rats ingested a greater amount of L-NAME than control animals. The average dose of L-NAME ingested by CRF rats was $5.2 \pm 0.26 \mathrm{mg} / 24 \mathrm{~h}$, significantly higher than control animals $(2.2 \pm 0.05 \mathrm{mg} / 24 \mathrm{~h}, P<0.01)$.

Table I. Blood Pressure and Body Weight in CRF and Control (C) Rats with or without Arginine (Arg) or L-NAME

\begin{tabular}{|c|c|c|c|c|c|c|}
\hline Weeks & 0 & 1 & 2 & 3 & 4 & 5 \\
\hline \multicolumn{7}{|l|}{ Blood pressure } \\
\hline CRF (20) & $126 \pm 1.3$ & $157 \pm 1.4^{*}$ & $155 \pm 2.9 *$ & $174 \pm 2.4^{*}$ & $183 \pm 2.5^{*}$ & $181 \pm 1.3^{*}$ \\
\hline $\mathrm{CRF}+\operatorname{Arg}(18)$ & $130 \pm 0.9$ & $143 \pm 1.1^{*}$ & $144 \pm 1.2 *$ & $142 \pm 1.0^{*}$ & $154 \pm 0.9 *$ & $154 \pm 0.7 *$ \\
\hline CRF + L-NAME (23) & $128 \pm 0.6$ & $184 \pm 4.4 *$ & $186 \pm 3.4 *$ & $217 \pm 4.0^{*}$ & & \\
\hline Control (15) & $125 \pm 1.0$ & $126 \pm 1.0$ & $123 \pm 1.4$ & $125 \pm 1.4$ & $126 \pm 1.3$ & $127 \pm 1.0$ \\
\hline$C+\operatorname{Arg}(15)$ & $127 \pm 0.7$ & $128 \pm 1.1$ & $123 \pm 1.4$ & $125 \pm 1.4$ & $126 \pm 1.3$ & $126 \pm 0.9$ \\
\hline C + L-NAME (17) & $131 \pm 0.5$ & $149 \pm 0.9 *$ & $151 \pm 2.3 *$ & $160 \pm 2.2 *$ & $158 \pm 2.2 *$ & $164 \pm 2.0^{*}$ \\
\hline \multicolumn{7}{|l|}{ Body weight } \\
\hline $\mathrm{CRF}$ & $298 \pm 2.5$ & $325 \pm 2.9$ & $342 \pm 2.8$ & $348 \pm 2.5$ & $363 \pm 2.5$ & $373 \pm 2.5$ \\
\hline $\mathrm{CRF}+\mathrm{Arg}$ & $296 \pm 1.0$ & $321 \pm 1.9$ & $339 \pm 2.3$ & $360 \pm 1.8$ & $364 \pm 1.3$ & $373 \pm 2.1$ \\
\hline $\mathrm{CRF}+\mathrm{L}-\mathrm{NAME}$ & $298 \pm 1.1$ & $323 \pm 2.1$ & $335 \pm 3.2$ & $343 \pm 4.7$ & & \\
\hline Control & $294 \pm 1.0$ & $346 \pm 1.4$ & $388 \pm 1.6$ & $422 \pm 2.6$ & $431 \pm 1.5$ & $449 \pm 1.6$ \\
\hline $\mathrm{C}+\mathrm{Arg}$ & $297 \pm 1.0$ & $391 \pm 2.3$ & $387 \pm 1.5$ & $427 \pm 1.8$ & $431 \pm 1.5$ & $447 \pm 1.6$ \\
\hline $\mathrm{C}+\mathrm{L}-\mathrm{NAME}$ & $294 \pm 2.2$ & $350 \pm 2.5$ & $370 \pm 2.2$ & $390 \pm 2.0$ & $395 \pm 1.8$ & $405 \pm 2.2$ \\
\hline \multicolumn{7}{|l|}{ Serum creatinine } \\
\hline $\mathrm{CRF}$ & $0.40 \pm 0.03$ & $1.30 \pm 0.02^{* \neq}$ & & $1.33 \pm 0.07 * \neq$ & & $1.40 \pm 0.02 * \dot{\xi}$ \\
\hline $\mathrm{CRF}+\mathrm{Arg}$ & $0.37 \pm 0.01$ & $1.37 \pm 0.05^{* \ddagger}$ & & $1.36 \pm 0.04^{* \ddagger}$ & & $1.53 \pm 0.05^{* \grave{亠}}$ \\
\hline CRF + L-NAME & $0.38 \pm 0.01$ & $1.41 \pm 0.06^{* \ddagger}$ & & $1.39 \pm 0.05^{* \neq}$ & & \\
\hline Control & $0.40 \pm 0.02$ & $0.42 \pm 0.02$ & & $0.39 \pm 0.02$ & & $0.45 \pm 0.05$ \\
\hline $\mathrm{C}+\mathrm{Arg}$ & $0.34 \pm 0.01$ & $0.38 \pm 0.03$ & & $0.37 \pm 0.03$ & & $0.40 \pm 0.03$ \\
\hline $\mathrm{C}+\mathrm{L}-\mathrm{NAME}$ & $0.36 \pm 0.02$ & $0.42 \pm 0.02$ & & $1.41 \pm 0.02$ & & $0.41 \pm 0.01$ \\
\hline
\end{tabular}

$* P<0.05$ compared with baseline values; ${ }^{\ddagger} P<0.05$ compared with controls. In parentheses are the number of rats studied for each group. Only few $\mathrm{CRF}+\mathrm{L}-\mathrm{NAME}$ rats survived after the third week. 
A

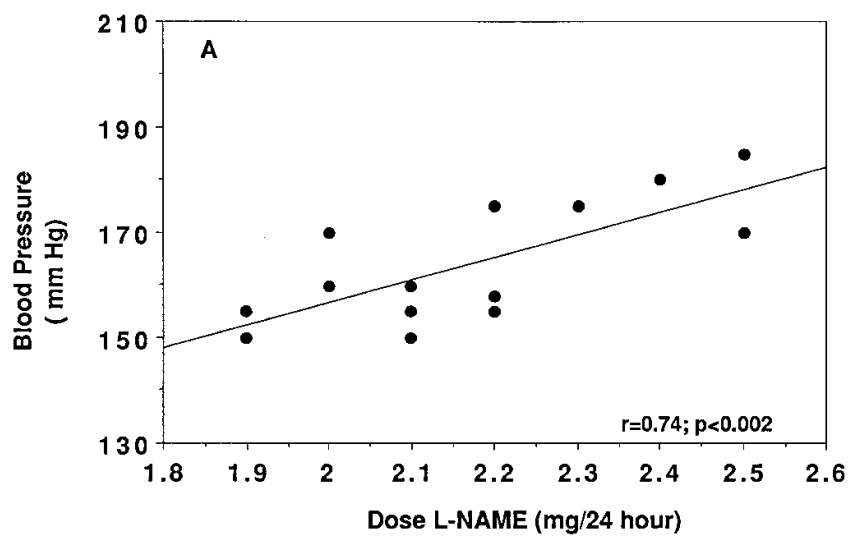

B

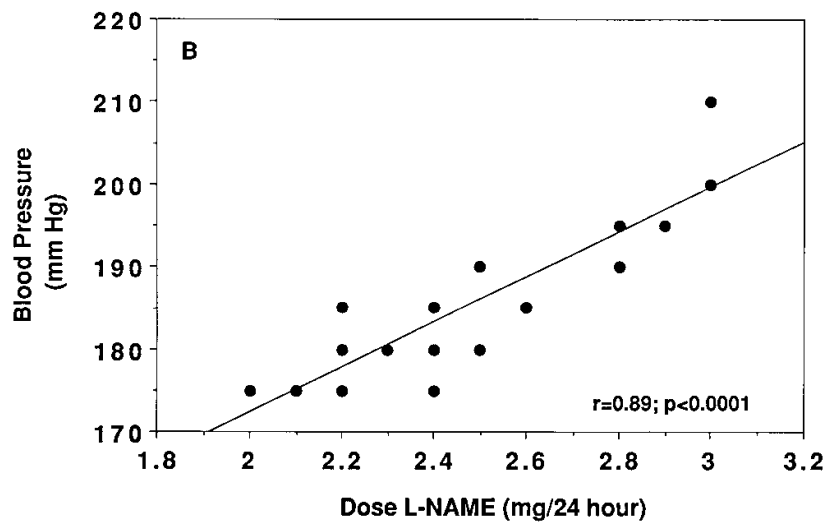

Figure 1. (A) Correlation between the average dose of L-NAME $(\mathrm{mg} / 24 \mathrm{~h})$ ingested by control rats for the entire duration of the study and the levels of systolic blood pressure at the end of the fifth week of treatment with L-NAME (50 mg/liter of drinking water). (B) Correlation between the average dose of L-NAME $(\mathrm{mg} / 24 \mathrm{~h})$ ingested by $5 / 6$ nephrectomized rats for the entire duration of the study and the levels of systolic blood pressure at the end of the third week of treatment with L-NAME $(25 \mathrm{mg} /$ liter of drinking water $)$.

When we repeated the experiment by giving CRF rats a reduced amount of L-NAME in the drinking water $(25 \mathrm{mg} / \mathrm{liter})$ systolic blood pressure reached levels of $186 \pm 1.9 \mathrm{mmHg}$ after $3 \mathrm{wk}$ of treatment and the average intake of L-NAME $(2.5 \pm 0.07 \mathrm{mg} / 24 \mathrm{~h})$ was not different than in control rats.

There was a significant correlation between the dose of L-NAME ingested and the levels of systolic blood pressure both in CRF $(r=0.89 ; P<0.0001)$ and control rats $(r=0.74$; $P<0.002$; Fig. $1, A$ and $B)$. In CRF rats treated with L-NAME serum creatinine was $0.38 \pm 0.01 \mathrm{mg} / \mathrm{dl}$ before nephrectomy and increased to $1.4 \pm 0.06 \mathrm{mg} / \mathrm{dl}$ after $1 \mathrm{wk}$, and to $1.39 \pm 0.07$ $\mathrm{mg} / \mathrm{dl} 3$ wk after the 5/6 nephrectomy. In control rats treated with L-NAME serum creatinine was $0.36 \pm 0.02 \mathrm{mg} / \mathrm{dl}$ at baseline and $0.41 \mathrm{mg} / \mathrm{dl}$ after $5 \mathrm{wk}$ of treatment.

Norepinephrine turnover in the brain. The endogenous concentration of NE and NE turnover rate in the posterior hypothalamic nuclei, locus coeruleus, and paraventricular nuclei were greater in CRF than control rats (Table II). Treatment with L-NAME increased NE turnover rate in the posterior hypothalamic nuclei, locus coeruleus, nucleus tractus solitarius, and paraventricular nuclei of both control and CRF rats. Treatment with L-arginine caused a significant decrease in NE turnover rate in the nucleus tractus solitarius of control rats, and a significant decrease in NE turnover rate in the locus coeruleus of CRF rats (Table II).

The endogenous concentration of epinephrine and the epinephrine turnover rate were greater in the C- 1 area of CRF than control rats (Table II). Treatment with L-NAME increased, whereas treatment with $\mathrm{L}$-arginine decreased the epinephrine turnover rate in the $\mathrm{C}-1$ region of CRF rats. The turnover rate of NE was not different in the rostral ventral medulla of CRF and sham-operated rats. L-NAME caused a significant rise in NE turnover rate in the rostral ventral medulla of both CRF and control rats, but the increase was greater in $\mathrm{CRF}$ than control rats. The content and turnover rate of NE in the rostral ventral medulla were significantly lower than the content and turnover rate of epinephrine both in CRF and control animals (Table II).

Norepinephrine turnover in the aorta. The endogenous concentration of $\mathrm{NE}$ and $\mathrm{NE}$ turnover rate in the aorta of CRF rats were greater than in control rats (Table III). Treatment with L-NAME increased the NE turnover rate in CRF rats.

Semiquantification of the RT-PCR products. For the purpose of semiquantification of the RT-PCR, two conditions have to be met. Firstly, it is necessary to determine the ideal number of PCR cycles needed to find the exponential phase of amplification in order to avoid reaching the plateau phase of amplification. Therefore, PCR were performed with varying number of reaction cycles and the PCR products were measured. Fig. 2 shows the results of the amplification of NOS and $\beta$-actin message with varying numbers of PCR cycles and their quantification using the fluorescence method mentioned above. For NOS the midpoint of the exponential phase of the RT-PCR amplification was at $\sim 28$ cycles, and for $\beta$-actin at $\sim 25$ cycles.

Secondly, it is essential to correct the amplification process for tube-to-tube variability in amplification efficiency. In order to accomplish this task, endogenous or exogenous standard can be used as a control. In our study, $\beta$-actin message was used as internal standard for semiquantification of PCR product. The greatest advantage of using endogenous standard is that the reference mRNA and the target mRNA are processed together for the entire duration of the experiment, from RNA extraction to PCR amplification. To confirm the reliability of the semiquantitative method employed above, we extracted total RNA from posterior hypothalamic nuclei of normal rats, we diluted it in different concentrations and performed RTPCR at 28 cycles for NOS and at 25 cycles for $\beta$-actin. There was a significant linear correlation between total RNA and PCR products for both NOS and $\beta$-actin (Fig. 3). Furthermore, a significant linear correlation between NOS and $\beta$-actin PCR products for various quantity of starting total RNA was demonstrated (Fig. 4). In all, these studies attest to the reliability of the semiquantitative power of the RT-PCR method used in this study for quantification of NOS and the internal control $\beta$-actin message.

NO content and NOS expression in brain nuclei. NO content was greater in all brain nuclei of CRF than control rats (Table IV). NOS mRNA expression was also greater in all brain nuclei of CRF compared with control rats (Table IV).

In CRF rats, we observed a significant relationship between the percent increment in NO synthase expression re- 
Table II. Endogenous NE and Epinephrine (E) Concentration and Turnover Rate in Several Brain Regions of 5/6 Nephrectomized $C R F$ and Control Rats with or without Treatment with L-Arginine (Arg) and L-NAME

\begin{tabular}{|c|c|c|c|c|}
\hline & Endogenous NE & $K$ & Turnover rate & $t_{1 / 2}$ \\
\hline & pg/mg tissue & $h^{-1}$ & $p g / m g / h$ & $h$ \\
\hline \multicolumn{5}{|c|}{ Anterior hypothalamus } \\
\hline Control & $4,542 \pm 250$ & $0.056 \pm 0.010$ & $255 \pm 45.0$ & 7.7 \\
\hline $\mathrm{C}+\mathrm{Arg}$ & $3,844 \pm 91$ & $0.042 \pm 0.004$ & $161 \pm 15.4$ & 10.3 \\
\hline $\mathrm{C}+\mathrm{LNAME}$ & $10,750 \pm 506^{*}$ & $0.027 \pm 0.003$ & $290 \pm 32.3^{*}$ & 16.0 \\
\hline CRF & $4,533 \pm 315$ & $0.046 \pm 0.008$ & $209 \pm 36.4$ & 9.4 \\
\hline $\mathrm{CRF}+\mathrm{Arg}$ & $4,203 \pm 324$ & $0.034 \pm 0.003$ & $144 \pm 12.6$ & 12.7 \\
\hline CRF + L-NAME & $8,616 \pm 154 *$ & $0.039 \pm 0.005$ & $336 \pm 43$ & 11.1 \\
\hline \multicolumn{5}{|l|}{ Posterior hypothalamus } \\
\hline Control & $11,708 \pm 477$ & $0.055 \pm 0.006$ & $643 \pm 70.2$ & 7.9 \\
\hline $\mathrm{C}+\mathrm{Arg}$ & $12,344 \pm 554$ & $0.069 \pm 0.006$ & $851 \pm 74.1$ & 6.3 \\
\hline $\mathrm{C}+\mathrm{L}-\mathrm{NAME}$ & $17,426 \pm 415^{*}$ & $0.075 \pm 0.004$ & $1,305 \pm 69.7 *$ & 5.8 \\
\hline $\mathrm{CRF}$ & $24,254 \pm 473^{*}$ & $0.080 \pm 0.012$ & $1,940 \pm 291 *$ & 5.4 \\
\hline $\mathrm{CRF}+\mathrm{Arg}$ & $20,313 \pm 825^{*}$ & $0.078 \pm 0.003$ & $1,586 \pm 60.9^{*}$ & 5.6 \\
\hline CRF + L-NAME & $42,150 \pm 1,435^{* \neq}$ & $0.110 \pm 0.008$ & $4,636 \pm 337 * \frac{\cdots}{\ddagger}$ & 3.9 \\
\hline \multicolumn{5}{|l|}{ Locus coeruleus } \\
\hline Control & $7,260 \pm 411$ & $0.048 \pm 0.008$ & $351 \pm 58.1$ & 9.0 \\
\hline $\mathrm{C}+\mathrm{Arg}$ & $6,976 \pm 234$ & $0.045 \pm 0.004$ & $310 \pm 29.9$ & 9.8 \\
\hline $\mathrm{C}+\mathrm{L}-\mathrm{NAME}$ & $7,680 \pm 359$ & $0.066 \pm 0.004$ & $506 \pm 30.7^{*}$ & 6.6 \\
\hline $\mathrm{CRF}$ & $11,055 \pm 398 *$ & $0.068 \pm 0.008$ & $752 \pm 88.4^{*}$ & 6.4 \\
\hline $\mathrm{CRF}+\mathrm{Arg}$ & $8,419 \pm 271$ & $0.034 \pm 0.002$ & $282 \pm 17.3^{* *}$ & 5.6 \\
\hline CRF + L-NAME & $17,093 \pm 151^{* \ddagger}$ & $0.149 \pm 0.030$ & $2,547 \pm 512 * \ddagger$ & 2.9 \\
\hline \multicolumn{5}{|c|}{ Nucleus tractus solitarius } \\
\hline Control & $4,698 \pm 369$ & $0.038 \pm 0.008$ & $178 \pm 42.3$ & 11.5 \\
\hline $\mathrm{C}+\mathrm{Arg}$ & $4,018 \pm 334$ & $0.041 \pm 0.005$ & $163 \pm 20.1$ & 10.7 \\
\hline $\mathrm{C}+\mathrm{L}-\mathrm{NAME}$ & $6,807 \pm 387$ & $0.048 \pm 0.004$ & $329 \pm 20.4 *$ & 9.0 \\
\hline $\mathrm{CRF}$ & $6,103 \pm 268 *$ & $0.040 \pm 0.009$ & $244 \pm 54.9^{*}$ & 11.0 \\
\hline $\mathrm{CRF}+\mathrm{Arg}$ & $5,256 \pm 189$ & $0.062 \pm 0.007$ & $326 \pm 36.8$ & 7.0 \\
\hline CRF + L-NAME & $17,563 \pm 4528^{*}$ & $0.120 \pm 0.008$ & $2,107 \pm 140^{* \ddagger}$ & 3.6 \\
\hline \multicolumn{5}{|l|}{ Paraventricular nuclei } \\
\hline Control & $15,492 \pm 1,353$ & $0.023 \pm 0.008$ & $350 \pm 124$ & 19.2 \\
\hline $\mathrm{C}+\mathrm{Arg}$ & $15,357 \pm 956$ & $0.040 \pm 0.007$ & $613 \pm 109$ & 10.9 \\
\hline $\mathrm{C}+\mathrm{L}-\mathrm{NAME}$ & $28,709 \pm 915^{*}$ & $0.075 \pm 0.008$ & $2,153 \pm 227 *$ & 5.8 \\
\hline $\mathrm{CRF}$ & $15,734 \pm 869 *$ & $0.044 \pm 0.010$ & $692 \pm 157$ & 9.9 \\
\hline $\mathrm{CRF}+\mathrm{Arg}$ & $15,823 \pm 1,208$ & $0.037 \pm 0.008$ & $592 \pm 126$ & 11.6 \\
\hline CRF + L-NAME & $28,383 \pm 833^{* \ddagger}$ & $0.067 \pm 0.008$ & $1,902 \pm 227^{* \ddagger}$ & 6.5 \\
\hline \multicolumn{5}{|l|}{$\mathrm{C}-1$} \\
\hline Control & $3,659 \pm 471$ & $0.029 \pm 0.001$ & $105 \pm 3.4$ & 15.1 \\
\hline $\mathrm{C}+\mathrm{Arg}$ & $3,863 \pm 336$ & $0.034 \pm 0.006$ & $131 \pm 24.7$ & 12.8 \\
\hline $\mathrm{C}+\mathrm{L}-\mathrm{NAME}$ & $10,768 \pm 455^{*}$ & $0.022 \pm 0.004$ & $236 \pm 40.9^{*}$ & 19.8 \\
\hline $\mathrm{CRF}$ & $5,234 \pm 339$ & $0.021 \pm 0.007$ & $111 \pm 36.6$ & 10.9 \\
\hline $\mathrm{CRF}+\mathrm{Arg}$ & $4,399 \pm 231$ & $0.003 \pm 0.005$ & $136 \pm 26$ & 14.0 \\
\hline CRF + L-NAME & $11,616 \pm 410^{* \ddagger}$ & $0.022 \pm 0.009$ & $255 \pm 105^{* \ddagger}$ & 19.7 \\
\hline \multicolumn{5}{|l|}{ A-1 } \\
\hline Control & $4,937 \pm 448$ & $0.050 \pm 0.010$ & $247 \pm 49.4$ & 8.7 \\
\hline $\mathrm{C}+\mathrm{Arg}$ & $4,896 \pm 232$ & $0.022 \pm 0.005$ & $108 \pm 25.9$ & 19.4 \\
\hline $\mathrm{C}+\mathrm{L}-\mathrm{NAME}$ & $5,248 \pm 144$ & $0.044 \pm 0.004$ & $232 \pm 21.0$ & 9.8 \\
\hline CRF & $5,997 \pm 188$ & $0.058 \pm 0.008$ & $348 \pm 48.0$ & 7.5 \\
\hline $\mathrm{CRF}+\mathrm{Arg}$ & $5,461 \pm 146$ & $0.038 \pm 0.004$ & $208 \pm 21.8$ & 11.5 \\
\hline \multirow[t]{3}{*}{ CRF + L-NAME } & $7,144 \pm 287$ & $0.085 \pm 0.004$ & $607 \pm 28.6$ & 5.1 \\
\hline & Endogenous E & K & Turnover rate & $t_{1 / 2}$ \\
\hline & pg/mg tissue & $h^{-1}$ & $\mathrm{pg} / \mathrm{mg} / \mathrm{h}$ & $h$ \\
\hline \multicolumn{5}{|l|}{ C-1 } \\
\hline Control & $6,731 \pm 152$ & $0.057 \pm 0.01$ & $384 \pm 67.3$ & 7.6 \\
\hline $\mathrm{C}+\mathrm{Arg}$ & $6,584 \pm 204$ & $0.051 \pm 0.01$ & $336 \pm 65.8$ & 8.5 \\
\hline $\mathrm{C}+\mathrm{L}-\mathrm{NAME}$ & $18,398 \pm 387 *$ & $0.061 \pm 0.01$ & $1,122 \pm 184^{*}$ & 7.1 \\
\hline CRF & $13,320 \pm 469$ & $0.081 \pm 0.01$ & $1,079 \pm 133$ & 5.3 \\
\hline $\mathrm{CRF}+\mathrm{Arg}$ & $7,750 \pm 182$ & $0.064 \pm 0.01$ & $494 \pm 78$ & 6.8 \\
\hline CRF + L-NAME & $21,215 \pm 637 *$ & $0.086 \pm 0.01$ & $1,824 \pm 212 * \ddagger$ & 5.0 \\
\hline
\end{tabular}

${ }^{*} P<0.05$ compared with control; ${ }^{\ddagger} P<0.05$ compared with CRF. $K$, fractional turnover; L-NAME, ${ }^{\mathrm{w}}$ L-nitro-L-arginine-methyl ester. 
Table III. Endogenous NE Concentration and Turnover Rate in the Aorta of Control and 5/6 Nephrectomized CRF Rats Treated with Vehicle or L-NAME

\begin{tabular}{lcccc}
\hline & Endogenous NE & $K$ & Turnover rate & $t_{1 / 2}$ \\
\hline & $p g / g$ tissue & $h^{-1}$ & $p g / g / h$ & $h$ \\
& & & & \\
Control & $85,951 \pm 3,773$ & $0.036 \pm 0.004$ & $3,094 \pm 343$ & 7.7 \\
CRF & $134,171 \pm 3,132 *$ & $0.060 \pm 0.004$ & $8,050 \pm 537 *$ & 9.4 \\
CRF + L-NAME & $166,730 \pm 5,554 *$ & $0.074 \pm 0.005$ & $1,234 \pm 834 * \ddagger$ & 12.7
\end{tabular}

$* P<0.001$ compared with control; ${ }^{\ddagger} P<0.001$ compared with CRF. The analysis was performed by ANOVA and Scheffe's $F$ test. $K$, fractional turnover.

lated to the renal failure, and the percent changes in $\mathrm{NE}$ turnover rate after treatment with L-NAME (Fig. 5). The correlation, however, depends on one single point and it loses significance $(r=0.66 ; P<0.16)$ when the highest value corresponding to the nucleus tractus solitarius is deleted. A significant relationship was also present between the percent increment in NO synthase expression related to the renal failure, and the percent changes in NE content after treatment with L-NAME $(r=0.79 ; P<0.05)$. No significant correlation was present between the percent changes in NO content related to CRF and the percent changes in NE turnover rate after treatment with L-NAME.

To determine whether the increase in NOS mRNA gene expression may be a consequence of increased blood pressure, we infused angiotensin II (8-16 $\mathrm{ng} / \mathrm{min}$ i.v.) to five rats to achieve a rise in blood pressure of $\sim 180 \mathrm{mmHg}$, levels similar to those of CRF rats. Angiotensin II increased blood pressure and NOS mRNA gene expression (Table IV) but decreased NE secretion from the posterior hypothalamus (29).

\section{Discussion}

This study has shown that treatment with L-arginine attenuates the severity of hypertension in CRF rats, whereas treatment with L-NAME, a competitive inhibitor of NO synthase, causes accelerated hypertension and death from cerebral hemorrhage in most CRF rats 4 to $5 \mathrm{wk}$ after the 5/6 nephrectomy. As previously shown by others, administration of L-NAME increased

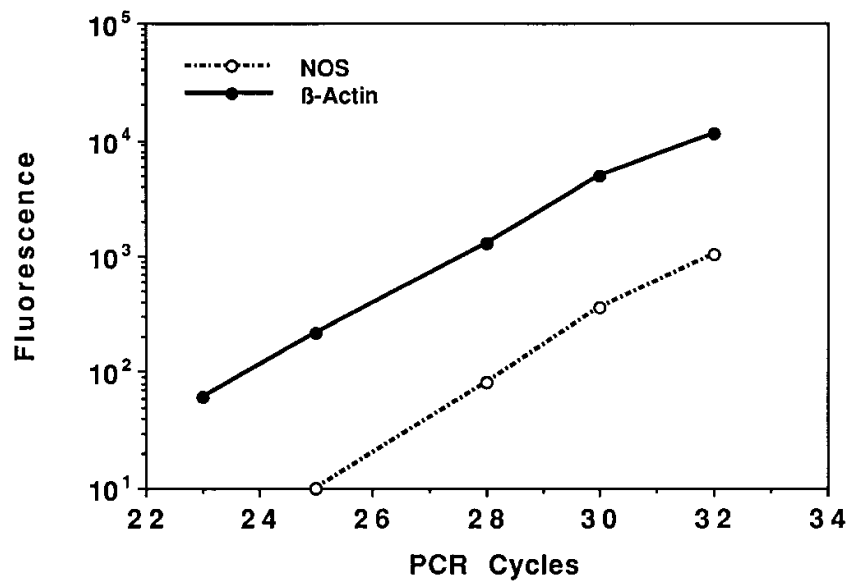

Figure 2. Relationship between PCR cycles and fluorescence quantitations. Kinetics of RT-PCR amplification of NOS gene mRNA, $\beta$-actin gene mRNA, and NOS/actin ratio with varying numbers of PCR cycles. Total RNA was extracted from the locus coeruleus of normal rats. RT-PCR products were quantified by fluorescence intensity of EB.

blood pressure in control rats. This supports the notion that basal nitric oxide release from peripheral resistance vessels exerts a tonic vasorelaxant action in vivo in normal animals (30-33). Our studies also indicate that basal NO release may exert a tonic vasorelaxant influence in CRF as well as control rats. We observed a dose-response relationship between the amount of L-NAME ingested and the severity of hypertension both in control and CRF rats. Treatment with L-arginine had no significant effect on blood pressure in control rats, but elicited a significant and sustained decline of blood pressure in CRF rats.

The mechanisms for the hypertensive action of L-NAME and the hypotensive effects of $\mathrm{L}$-arginine have been attributed largely to effects on endothelial NO synthase and NO production. However, recent studies have provided evidence that NO synthase is present in specific areas of the brain involved in the neurogenic control of blood pressure $(34,35)$. Studies in experimental animals have also provided convincing evidence that the neuronal isoform of NO synthase is an important compo-

Table IV. Semiquantitative Measurements of Nitric Oxide Synthase mRNA Gene Expression and $\mathrm{NO}_{2} / \mathrm{NO}_{3}(\mathrm{nmol} / \mathrm{mg}$ Tissue) in Several Brain Nuclei of Control (C) and 5/6 Nephrectomized CRF Rats

\begin{tabular}{|c|c|c|c|c|c|}
\hline & \multicolumn{3}{|c|}{ NOS mRNA } & \multicolumn{2}{|c|}{$\mathrm{NO}_{2} / \mathrm{NO}_{3}$} \\
\hline & $C$ & $C R F$ & Angio II & $C$ & $C R F$ \\
\hline Anterior hypothalamus & $25.6 \pm 3.26$ & $60.1 \pm 10.4^{*}$ & $56 \pm 1.5^{*}$ & $0.87 \pm 0.04$ & $1.8 \pm 0.06^{\ddagger}$ \\
\hline Posterior hypothalamus & $32.0 \pm 2.79$ & $106.8 \pm 9.18^{*}$ & $70 \pm 1.6^{*}$ & $1.2 \pm 0.7$ & $4.1 \pm 0.08^{\ddagger}$ \\
\hline Locus coeruleus & $31.7 \pm 5.81$ & $94.6 \pm 6.21 *$ & $58 \pm 2.8^{*}$ & $1.2 \pm 0.08$ & $3.1 \pm 0.06^{\ddagger}$ \\
\hline Nucleus tractus solitarius & $21.9 \pm 0.98$ & $93.4 \pm 11.2 *$ & $60 \pm 1.2 *$ & $0.76 \pm 0.04$ & $1.8 \pm 0.05^{\ddagger}$ \\
\hline Paraventricular nuclei & $24.8 \pm 3.86$ & $65.9 \pm 1.77 *$ & $65 \pm 2.9 *$ & $0.5 \pm 0.06$ & $2.3 \pm 0.08^{\ddagger}$ \\
\hline C-1 & $53.0 \pm 4.38$ & $139.7 \pm 13.5^{*}$ & $68 \pm 3.5^{*}$ & $1.0 \pm 0.04$ & $4.0 \pm 0.07^{\ddagger}$ \\
\hline A-1 & $45.3 \pm 4.78$ & $87.2 \pm 8.86^{*}$ & $74 \pm 3.6$ & $2.2 \pm 0.13$ & $4.2 \pm 0.11^{\ddagger}$ \\
\hline Cerebral cortex & $25.3 \pm 2.3$ & $35.5 \pm 1.5^{\S}$ & - & $0.11 \pm 0.03$ & $0.75 \pm 0.07^{\text {* }}$ \\
\hline
\end{tabular}

$* P<0.01 ;{ }^{\ddagger} P<0.0001 ;{ }^{\S} P<0.02$ compared with control rats. Data on angio II refer to levels of mRNA gene expression after intravenous infusion of angiotensin II (8-16 $\mathrm{ng} / \mathrm{min})$ to achieve a systolic blood pressure of $\sim 180 \mathrm{mmHg}$. 


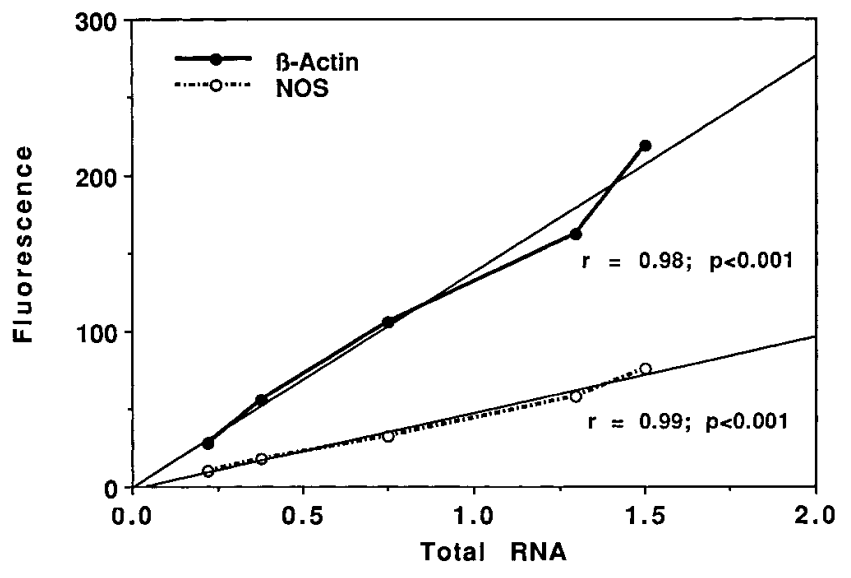

Figure 3. Correlation between total RNA and PCR products for both NOS and $\beta$-actin in the posterior hypothalamic nuclei of normal rats. Total RNA was extracted from the posterior hypothalamic nuclei of four normal rats and diluted in $40 \mu 1 \mathrm{H}_{2} \mathrm{O}$. Thus, $15 \mu \mathrm{l}$ correspond to the total RNA contained in 1.5 rats; $11.3 \mu \mathrm{l}$ correspond to the total RNA of 1.13 rats; $7.5 \mu \mathrm{l}$ to $0.75 ; 3.8 \mu \mathrm{l}$ to 0.38 ; and $2.0 \mu \mathrm{l}$ correspond to the total RNA contained in 0.2 rat.

nent of the transduction pathways that tonically inhibit sympathetic outflow from the brain stem (36-40). Thus, the hypertensive effect of L-NAME in the rat could be partly due to activation of central noradrenergic neurons.

We have previously shown that the turnover rate of $\mathrm{NE}$ was significantly increased in the posterior hypothalamic nuclei and in the locus coeruleus of 5/6 nephrectomized rats, and chemical destruction of the posterior hypothalamic nuclei by microinjection of a neurotoxin, 6-OH-dopamine, reduced blood pressure in these animals (9). We have also shown that NE secretion from the posterior hypothalamic nuclei is increased in CRF rats (29). Studies in our laboratory have demonstrated that bilateral dorsal rhizotomy (T-10 to L-2) prevents the development of hypertension and the increase in NE turnover rate and release in the posterior hypothalamic nuclei in CRF rats (41). This suggests that afferent impulses from damaged kidneys may activate areas of the brain involved in the noradrenergic regulation of blood pressure and contribute to the de-

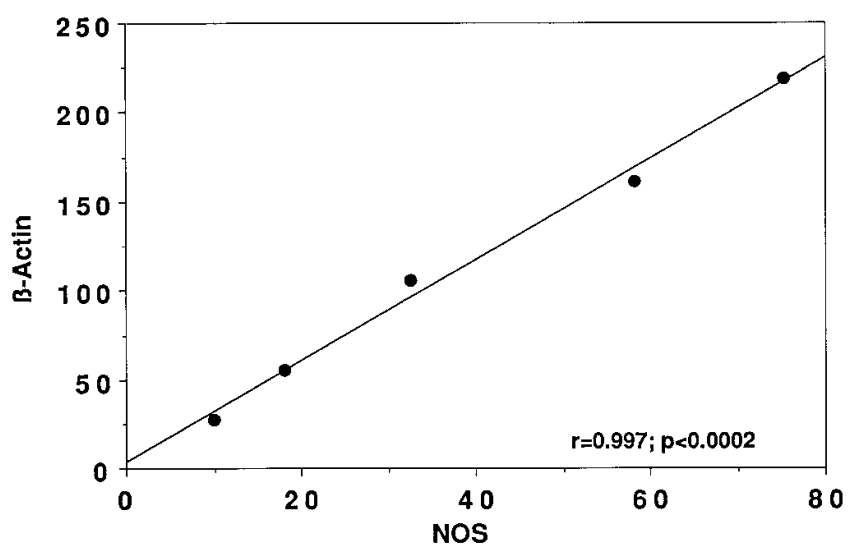

Figure 4. Correlation between NOS and $\beta$-acting PCR products for various quantity of starting total RNA extracted from the posterior hypothalamic nuclei of normal rats.

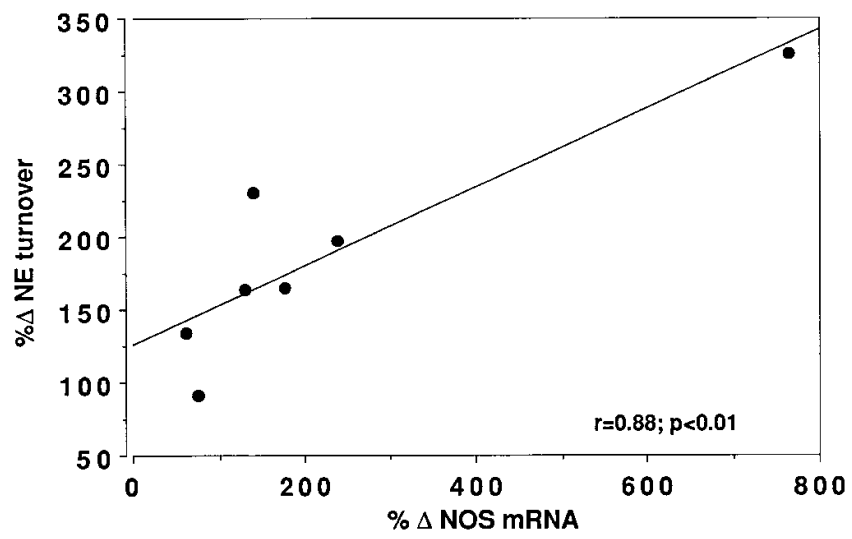

Figure 5. Correlation between the percent change in NOS gene expression related to $\mathrm{CRF}$ and the percent increment in NE turnover rate in seven different brain nuclei (the anterior and posterior hypothalamic nuclei, the locus coeruleus, the nucleus tractus solitarius, the paraventricular nuclei and the $\mathrm{C}-1$ and $\mathrm{A}-1$ regions) after treatment of CRF rats with L-NAME ( $25 \mathrm{mg} /$ liter of drinking water).

velopment of hypertension (42-47). This notion is supported by the study of Converse et al. (48) who showed that the decrease in arterial pressure after bilateral nephrectomy in uremic patients on chronic dialysis, was associated with lower sympathetic nerve firing and regional vascular resistance.

To determine whether the increased activity of central noradrenergic neurons of CRF rats is associated with an increase in peripheral SNS activity, we measured NE turnover rate in the aorta of CRF and control rats. We showed that NE turnover was greater in the thoracic aorta of CRF than control rats. This suggests that the peripheral as well as the central SNS activity are increased in CRF rats.

The role of NO in chronic renal failure remains controversial. Vallance et al. (49) showed increased plasma levels of an endogenous compound, $\mathrm{N}^{\mathrm{G}} \mathrm{N}^{\mathrm{G}}$-dimethylarginine (asymmetrical dimethylarginine, ADMA) and lower plasma arginine/dimethylarginine ratio in uremic patients on chronic hemodialysis compared to normal individuals. Because ADMA inhibits NO synthesis both in vitro and in vivo, the authors suggested that hypertension in the uremic patient on maintenance dialysis could be due, at least in part, to inhibition of NO synthesis caused by increased levels of this compound. This notion, however, is not substantiated by the studies of Remuzzi et al. who observed increased NO synthesis in platelets from patients and rats with CRF $(50,51)$. They also showed that uremic plasma increased NO synthesis by endothelial cells in culture, suggesting that a circulating factor may be responsible for this action. In the current studies we have shown increased NO and NOS mRNA gene expression in several brain nuclei. Moreover, administration of L-NAME to CRF rats, increased blood pressure and NE turnover rate in all areas of the brain studied. These findings support the notion that the production of $\mathrm{NO}$ is increased in CRF rats and it exerts a tonic inhibition of $\mathrm{NE}$ turnover in several brain regions. The hypertensive action of L-NAME may be due, at least in part, to activation of central noradrenergic neurons.

In some brain regions, such as the posterior hypothalamic nuclei, the locus coeruleus, and the nucleus tractus solitarius, the increase in NE turnover caused by L-NAME was more pronounced in CRF than in control rats. In CRF rats, there 
was a significant relationship between the percent increment in NOS gene expression, and the percent increase in NE turnover rate after treatment with L-NAME (Fig. 6). This supports the notion that endogenous NO exerts a tonic inhibition of central noradrenergic neurons involved in blood pressure regulation, and this inhibition is enhanced in CRF rats to mitigate the rise in blood pressure.

The mechanisms responsible for the increased $\mathrm{NO}$ and NOS mRNA expression in brain nuclei of CRF rats are not clear. It is possible that they may be a consequence of increased blood pressure or secretion of pressor hormones such as norepinephrine, angiotensin II, and aldosterone. We cannot also rule out the possibility that the uremic milieu might stimulate NOS mRNA expression. The studies of Remuzzi et al. suggest that a circulating factor may be responsible for this action.

One could speculate that the increase in NE turnover in the posterior hypothalamus is the consequence rather than the cause of hypertension. This, however, is unlikely because NE turnover in this region increases when arterial pressure falls and decreases when arterial pressure rises $(52,53)$. We have shown that administration of angiotensin II to rats in doses that increased blood pressure to $180 \mathrm{mmHg}$, caused a significant decrease in NE secretion from the posterior hypothalamic nuclei (29) and an increase in NOS mRNA gene expression in several brain nuclei (Table IV). There is also substantial evidence that an increase in noradrenergic activity in the posterior hypothalamus is associated with increased peripheral SNS activity and blood pressure. Electrical stimulation of the posterior hypothalamic areas increases blood pressure in the rat (42, $43,54)$, and destruction of these areas decrease blood pressure in SHR rats (55). Local perfusion of hypertonic saline or phenylephrine in the posterior hypothalamus elicited increased blood pressure, heart rate, and NE release (56). On the other hand, blockade of $\alpha$-adrenergic receptors with phenoxybenzamine prevented the cardiovascular effects caused by the administration of $\mathrm{NaCl}$ or phenylephrine in this area. These data strongly indicate that the increase in NE release and turnover in this region are associated with increased peripheral SNS activity and hypertension. These hemodynamic effects depend on stimulation of $\alpha$-adrenergic receptors in this region. In all, these studies support the notion that increased noradrenergic outputs from the posterior hypothalamic nuclei may play a role in the maintenance of hypertension in CRF rats.

The rostral part of the ventrolateral medulla is a pressor region (57) from which bulbospinal presympathetic neurons descend to the intermediolateral cell column and integrative neurons connect with the posterior hypothalamic nuclei (47). This region contains several neurons with different neurotransmitters, including biogenic amines, acetylcholine, neuropeptides, aminoacids, and epinephrine $(58,59,60,61)$. Epinephrine but not norepinephrine appears to be an important neurotransmitter in this region. The turnover rate of epinephrine was greater in the rostral ventral medulla of CRF than control rats suggesting that noradrenergic activity is increased in this brain region of these rats. Because the posterior hypothalamus is under the direct influence of the rostral ventral medulla (61), the increase in norepinephrine turnover rate in the posterior hypothalamic nuclei and locus coeruleus, could be secondary to greater SNS activity in the rostral ventral medulla of CRF compared to control rats. The caudal ventrolateral (A-1) region, on the other hand, exerts inhibitory influences on the ros- tral pressor regions. Endogenous NO modulates baseline SNS outflow and excitatory responses in these regions (62).

Administration of L-arginine decreased NE turnover rate in the locus coeruleus of CRF rats. This suggests that the hypotensive action of L-arginine in part may be due to increased NO production and action on the peripheral resistance vessels, in part to inhibition of central noradrenergic neurons.

One limitation of our studies consists in blood pressure measurements done by the tail-cuff method. Even though we prewarm the animals for $15 \mathrm{~min}$ and measure blood pressure in a very quiet environment, measurements by the tail-cuff methods cause a certain amount of stress and are dependent on the activity of the SNS.

In summary, these studies have shown that the basal activity of the SNS in different brain nuclei of normal rats is regulated by local NO production. In CRF rats, the activity of the SNS is increased in the posterior hypothalamic nuclei and in the locus coeruleus, and this increase is partially mitigated by enhanced local NOS gene expression. This is supported by worsening of norepinephrine turnover and blood pressure after administration of L-NAME and by the significant correlation between the increase in NOS gene expression and the increase in NE turnover after L-NAME.

\section{Acknowledgments}

This study was supported by National Institutes of Health grants 1-RO1-HL-47881 and RO1-HL-35629, and by an Extramural Grant from Baxter Healthcare Group.

\section{References}

1. Schalekamp, M.A.D.H., M.P.A. Schalekamp-Kuyken, M. de MoorFruytier, T. Meininger, D.J. Vaandrager-Kranenburg, and W.H. Birkenhager. 1973. Interrelationships between blood pressure, renin, renin substrate and blood volume in terminal renal failure. Clin. Sci. Mol. Med. 45:417-428.

2. Lazarus, J.M., C.L. Hampers, and J.P. Merrill. 1974. Hypertension in chronic renal failure. Treatment with hemodialysis and nephrectomy. Arch. Intern. Med. 133:1059-1066.

3. Atuk, N.O., C.J. Bailey, S. Turner, M.J. Peach, and F.B. Westervelt, Jr. 1976. Red blood cell catechol-o-methyl transferase, plasma catecholamines and renin in renal failure. Trans. Am. Soc. Artif. Intern. Organs. 22:195-200.

4. Lake, C.R., M.G. Ziegler, M.D. Coleman, and I.J. Kopin. 1979. Plasma levels of norepinephrine and dopamine-beta-hydroxylase in CRF patients treated with dialysis. Cardiovasc. Med. 1:1099-1111.

5. Henrich, W.L., F.H. Katz, P.B. Molinoff, and R.W. Schrier. 1977. Competitive effects of hypokalemia and volume depletion on plasma renin activity, aldosterone and catecholamine concentrations in hemodialysis patients. Kidney Int. 12:279-284.

6. Izzo, J.L. Jr., M.S. Izzo, R.H. Sterns, and R.B. Freeman. 1982. Sympathetic nervous system hyperactivity in maintenance hemodialysis patients. Trans. Am. Soc. Artif. Intern. Organs. 28:604-607.

7. Cuche, J.L., J. Prinseau, F. Selz, G. Ruget, and A. Baglin. 1986. Plasma free, sulfo- and glucuro-conjugated catecholamines in uremic patients. Kidney Int. 30:566-572.

8. Yanagisawa, M., H. Kurihara, S. Kimura, T. Yoko, M. Kobayashi, Y. Mitsui, Y. Yazaki, K. Goto, and T. Masaki. 1988. A novel potent vasoconstrictor peptide produced by vascular endothelial cells. Nature (Lond.). 332:411415.

9. Bigazzi, R., E. Kogosov, and V.M. Campese. 1994. Altered norepinephrine turnover in the brain of rats with chronic renal failure. J. Am. Soc. Nephrol. 4:1901-1907.

10. Furchgott, R.F., J.V. Zawadzki. 1980. The obligatory role of endothelial cells in the relaxation of arterial smooth muscle by acetylcholine. Nature (Lond.). 288:373-376.

11. Palmer, R.M., A.G. Ferrige, and S. Moncada. 1987. Nitric oxide release accounts for the biological activity of endothelium-derived relaxation factor. Nature (Lond.). 327:524-526.

12. Amezcua, J.L., G.J. Dusting, R.M. Palmer, and S. Moncada. 1988. Acetylcholine induces vasodilation in the rabbit isolated heart through release of nitric oxide, the endogenous vasodilator. Br. J. Pharmacol. 95:830-834.

13. Palmer, R.M., D.S. Ashton, and S. Moncada. 1988. Vascular endothelial 
cells synthesize nitric oxide from L-arginine. Nature (Lond.). 333:664-666.

14. Ignarro, L.J. 1990. Biosynthesis and metabolism of endothelium-derived nitric oxide. Annu. Rev. Pharmacol. Toxicol. 30:535-560.

15. Palmer, R.M.J., D.D. Rees, D.S. Ashron, and S. Moncada. 1988. L-arginine is the physiological precursor for the formation of nitric oxide in endothelium-dependent relaxation. Biochem. Biophys. Res. Commun. 153:1251-1256.

16. Hu, L., R. Manning, Jr., and M.W. Brands. 1994. Long-term cardiovascular role of nitric oxide in conscious rats. Hypertension. 23:185-194.

17. Johnson, R.A., and R.H. Freeman. 1992. Sustained hypertension in the rat induced by chronic blockade of nitric oxide production. Am. J. Hypertens. 5(part 1):919-922.

18. Ribiero, M.O., G. de Nucci, and R. Zatz. 1991. Persistant arterial hypertension by chronic blockade of nitric oxide synthesis. J. Am. Soc. Nephrol. 2: $512 \mathrm{~A}$.

19. Sakuma, I., H. Togashi, M. Yoshioka, H. Saito, M. Yanagida, M. Tamura, T. Kobayashi, H. Yasuda, S.S. Gross, and R. Levi. 1992. N ${ }^{\mathrm{G}}$-methylL-arginine, an inhibitor of L-arginine-derived nitric oxide synthesis, stimulates renal sympathetic nerve activity. Circ. Res. 70:607-611.

20. Glowinski, J., and L. Iversen. 1966. Regional studies of catecholamines in the rat brain. The disposition of $\left[{ }^{3} \mathrm{H}\right]$ norepinephrine, $\left[{ }^{3} \mathrm{H}\right]$ dopamine, and $\left[{ }^{3} \mathrm{H}\right]$ dopa in various regions of the brain. J. Neurochem. 13:665-669.

21. Palkovits, M., and L. Zaborszky. 1977. Neuroanatomy of central cardiovascular control. In Hypertension and Brain Mechanisms, Progress in Brain Research. W. de Jong, A.P. Provoost and A.P. Shapiro, editors. Elsevier Science Publishing Co. Inc., Amsterdam. 9-34

22. Peuler, J.D., and G.A. Johnson. 1977. Simultaneous single isotope radioenzymatic assay of plasma norepinephrine, epinephrine, and dopamine. Life Sci. 21:625-636.

23. Yoshida, T., and G.A. Bray. 1984. Catecholamine turnover in rats with ventromedial hypothalamic lesions. Am. J. Physiol. 246:R558-R565.

24. Fisler, J.S., T. Yoshida, and G.A. Bray. 1984. Catecholamine turnover in $\mathrm{S} 5 \mathrm{~B} / \mathrm{Pl}$ and Osborne-Mendel rats: response to a high fat diet. Am. J. Physiol. 247:R290-R295.

25. Spector, S., A. Sjoerdsma, and S. Udenfriend. 1965. Blockade of endogenous norepinephrine synthesis by -methyl-tyrosine, an inhibitor of tyrosine hydroxylase. J. Pharmacol. Exp. Ther. 147:86-95.

26. Brodie, B.B., E. Costa, A. Dlabac, N.H. Neff, and H.H. Smookler. 1966. Application of steady state kinetics to the estimation of synthesis rate and turnover time of tissue catecholamines. J. Pharmacol. Exp. Ther. 154:493-498.

27. Taubin, H.L., B. Djahanguiri, and L. Landsberg. 1972. Noradrenaline concentration and turnover in different regions of the gastrointestinal tract of the rat: an approach to the evaluation of sympathetic activity in the gut. Gut. 13: 790-795.

28. Higuchi, R., and G. Dollinger. 1992. Simultaneous amplification and detection of specific DNA sequences. Biotechnology. 10:413-417.

29. Ye, S.H., and V.M. Campese. 1997. Renal afferent impulses, the posterior hypothalamus, and hypertension in rats with chronic renal failure. Kidney Int. In press.

30. Aisaka, K., S.S. Gross, O.W. Griffith, and R. Levi. 1989. NG-Methylarginine, an inhibitor of endothelium-derived nitric oxide synthesis, is a potent pressor agent in the guinea pig: does nitric oxide regulate blood pressure in vivo? Biochem. Biophys. Res. Commun. 160:881-886.

31. Rees, D.D., R.M.J. Palmer, and S. Moncada. 1989. Role of endothelium-derived nitric oxide in the regulation of blood pressure. Proc. Natl. Acad. Sci. USA. 86:3375-3378.

32. Whittle, B.J., J. Lopez-Belmonte, and D.D. Rees. 1989. Modulation of the vasodepressor actions of acetylcholine, bardykinin, substance $\mathrm{P}$ and endothelin in the rat by a specific inhibitor of nitric oxide. Br. J. Pharmacol. 98:646652.

33. Kilbourn, R.G., S.S. Gross, A. Jubran, J. Adams, O.W. Griffith, R. Levi, and R.F. Lodato. 1990. $\mathrm{N}^{\mathrm{G}}$-Methyl-L-arginine inhibits tumor necrosis factorinduced hypotension: implications for the involvement of nitric oxide. Proc. Natl. Acad. Sci. USA. 87:3629-3632.

34. Bredt, D.S., P.M. Hwang, and S.H. Snyder. 1990. Localization of nitric oxide synthase indicating a neuronal role for nitric oxide. Nature (Lond.). 347: $768-770$

35. Vincent, S.R., and H. Kimura. 1992. Histochemical mapping of nitric oxide synthase in the rat brain. Neuroscience. 46:755-784.

36. Barinaga, M. 1991. Is nitric oxide the "retrograde messenger"? Science (Wash. DC). 254:1296-1297.

37. Togashi, H., I. Sakuma, M. Yoshioka, T. Kobayashi, H. Yasuda, A. Kitabatake, H. Saito, S.S. Gross, and R. Levi. 1992. A central nervous system action of nitric oxide in blood pressure regulation. J. Pharmacol. Exp. Ther. 262: $343-347$.
38. Shapoval, L.N., V.F. Sagach, and L.S. Pobegailo. 1991. Nitric oxide influences ventrolateral medullary mechanisms of vasomotor control in the cat. Neurosci. Lett. 132:47-50.

39. Harada, S., S. Tokunaga, M. Momohara, H. Masaki, T. Tagawa, T. Imaizumi, and A. Takeshita. 1993. Inhibition of nitric oxide formation in the nucleus tractus solitarius increases renal sympathetic nerve activity in rabbits. Circ. Res. 72:511-516.

40. Toda, N., Y. Kitamura, and T. Okamura. 1993. Neural mechanism of hypertension by nitric oxide synthase inhibitor in dogs. Hypertension. 21:3-8.

41. Campese, V.M., and E. Kogosov. 1995. Renal afferent denervation prevents hypertensin in rats with chronic renal failure. Hypertension. 25:878-882.

42. Enoch, D.M., and F.W.L. Kerr. 1967. Hypothalamic vasopressor and vesicopressor pathways. Arch. Neurol. 16:290-306.

43. Takeda, K., and R.D. Bunag. 1978. Sympathetic hyperactivity during hypothalamic stimulation in spontaneously hypertensive rats. J. Clin. Invest. 62 : 642-648.

44. Juskevich, J.C., D.S. Robinson, and D. Whitehorn. 1978. Effect of hypothalamic stimulation in spontaneously hypertensive and Wistar-Kyoto Rats. Eur. J. Pharmacol. 51:429-439.

45. Ward, D.G., and C.G. Gunn. 1976. Locus coeruleus complex: elicitation of a pressor response and a brain stem region necessary for its occurrence. Brain Res. 107:401-406.

46. Sakaguchi, T., M. Takahashi, and G.A. Bray. 1988. Lateral hypothalamus and sympathetic firing rate. Am. J. Physiol. 255:R507-R512.

47. Ciriello, J., and F.R. Calaresu. 1980. Role of paraventricular and supraoptic nuclei in central cardiovascular regulation in the cat. Am. J. Physiol. 239:R137-R142.

48. Converse, R.L., Jr, T.N. Jacobsen, R.D. Toto, C.M. Jost, F. Cosentino, F. Fouad-Tarazi, and R.G. Victor. 1992. Sympathetic overactivity in patients with CRF. N. Engl. J. Med. 327:1912-1918.

49. Vallance, P., A. Leone, A. Calver, J. Collier, and S. Moncada. 1992. Accumulation of an endogenous inhibitor of nitric oxide synthesis in chronic renal failure. Lancet. 339:572-575.

50. Noris, M., A. Benigni, P. Boccardo, S. Aiello, F. Gaspari, M. Todeschini, M. Figliuzzi, and G. Remuzzi. 1993. Enhanced nitric oxide synthesis in uremia: implications for platelet dysfunction and dialysis hypotension. Kidney Int. 44: 445-450.

51. Remuzzi, G., N. Perico, C. Zoja, D. Corna, D. Macconi, and G. Vigano. 1990. Role of endothelium-derived nitric oxide in the bleeding tendency of uremia. J. Clin. Invest. 86:1768-1771.

52. Patel, K.P., and R.L. Kline. 1984. Influence of renal nerves on noradrenergic responses to changes in arterial pressure. Am. J. Physiol. 247:R615-R620.

53. Chalmers, J.P. 1975. Brain amines and models of experimental hypertension. Circ. Res. 36:469-480.

54. Bunag, R.D., and A.E. Eferakeya. 1976. Immediate hypotensive aftereffects of posterior hypothalamic lesions in awake rats with spontaneous, renal, or DOCA hypertension. Cardiovasc. Res. 10:663-671.

55. Nakata, T., W. Berard, E. Kogosov, and N. Alexander. 1990. Microdialysis in the posterior hypothalamus: sodium chloride affects norepinephrine release, mean arterial pressure, heart rate and behavior in awake rats. Brain Res. Bull. 25:593-598.

56. Granata, A.R., D.A. Ruggiero, D.H. Park, T.H. Joh, and D.J. Reis. 1985. Brain stem area with $\mathrm{C} 1$ epinephrine neurons mediates baroreflex vasodepressor responses. Am. J. Physiol. 248:H547-H567.

57. Kalia, M., K. Fuxe, and M. Goldstein. 1985. Rat medulla oblongata. II Dopaminergic, noradrenergic (A1 and A2) and adrenergic neurons, nerve fibers, and presumptive terminal processes. J. Comp. Neurol. 233:308-332.

58. Armstrong, D.M., C.A. Ross, V.M. Pickel, T.H. Joh, and D.J. Reis 1982. Distribution of dopamine-, noradrenaline-, and adrenaline-containing cell bodies in the rat medulla oblongata: demonstrated by the immunocytochemical localization of catecholamine biosynthetic enzymes. J. Comp. Neurol. 212:173187.

59. Howe, P.R., M. Costa, J.B. Furness, and J.P. Chalmers. 1980. Simultaneous demonstration of phenylethanolamine N-methyltransferase immunofluorescent and catecholamine fluorescent nerve cell bodies in the rat medulla oblongata. Neuroscience. 5:2229-2238.

60. Ruggiero, D.A., P.J. Gatti, R.A. Gillis, W.P. Normon, M. Anwar, and D.J. Reis. 1986. Adrenaline-synthesizing neurons in the medulla of the cat. $J$. Comp. Neurol. 252:532-542.

61. Chalmers, J., and P. Pilowsky. 1991. Brainstem and bulbospinal neuratransmitter systems in the control of blood pressure. J. Hypertens. 9:675-694.

62. Zanzinger, J., J. Czachurski, and H. Seller. 1995. Inhibition of basal and reflex-mediated sympathetic activity in the RVLM by nitric oxide. Am. J. Physiol. 268:R958-R962. 